\title{
Schneider, Nina. Brazilian Propaganda: Legitimizing an Authoritarian Regime. Gainesville: University Press of Florida, 2014.
}

This book by Nina Schneider meaningfully contributes to an understanding of the Brazilian dictatorship of 1964 - 85, a field of study that is - due to the actions, or lack thereof of successive democratic governments - engulfed by an absence of historical truth. Schneider throughout the book seeks to redress this, show what kind of resources were utilised by the Brazilian civilian-military dictatorship, ${ }^{2}$ and illuminate the legacy of that illegitimate regime. In doing so the author not only refers to traditional investigations but also to recent works on transitional justice and Brazil's transition. ${ }^{3}$

Fifty years after the coup that seized political power from ex-President João Goulart and amid many new studies from Brazil and abroad, Brazilian Propaganda stands out by the singularity of its subject. Few books have been dedicated to the impact, reception and institutional structure of this form of propagating a doctrine (as stated in the $19^{\text {th }}$ century): using a broader concept that includes not only the standard notion of propaganda, but also education and information, Schneider is able to shed light on a field that has not been taken up by the National Truth Commission in Brazil. More than

\footnotetext{
${ }^{1}$ Adjunct Professor at the Federal University of Minas Gerais Law School. Post-doc. Visiting Researcher at the King's Brazil Institute, King's College London (2014/2015), financed by CAPES - Coordenação de Aperfeiçoamento de Pessoal de Nível Superior, Ministry of Education, process number 3192-14-8.

2 "Civilian-military dictatorship" is a term used by Schneider and other present-day authors that underline how the militaries were supported by civil actors before, during and after the coup.

${ }^{3}$ To quote a few examples: Atencio, Rebecca J.. Memory's Turn: Reckoning with Dictatorship in Brazil. Madison: The University of Wisconsin Press, 2014; Lessa, Francesca. Payne, Leigh A. (eds.). Amnesty in the Age of Human Rights Accountability: Comparative and International Perspectives. Cambridge: Cambridge University Press, 2012; Meyer, Emilio Peluso Neder. Cattoni de Oliveira, Marcelo Andrade (eds.). Justiça de Transição nos 25 Anos da Constituição de 1988. Belo Horizonte: Initia Via, 2014.
} 
that, the book shows how the closeness between the goals of the military, the civil media and advertisement groups came to have remarkable impact on what happens today in Brazilian politics.

Based on extensive research, Brazilian Propaganda is also a clear example of the author's persistence and sense of opportunity. She had several interviews with military officers in Brazil who, due to recent investigations made by Brazilian truth commissions and prosecutors, had generally refused to be interviewed. With a previous and wellgrounded knowledge of Brazilian dictatorship history, Schneider went through public archives, oral testimonies, documents and a vast bibliography in order to write a strong and persuasive text, giving due consideration to the multiple aspects involved in the investigation of historical facts. ${ }^{4}$

Brazilian Propaganda starts with a very interesting contextualization of the 1964 coup. Showing the several points of view inherent to any historical fact, Schneider describes the importance of the role played by institutions like the IPÊS (Instituto de Pesquisas e Estudos Sociais - Institute of Social Research and Study) and the IBAD (Instituto Brasileiro de Ação Democrática - Brazilian Institute for Democratic Action) in spreading ideas that were fundamental to "create" the necessary environment and step up popular support to the coup. This was done a few years after the foundation of the ESG (Escola Superior de Guerra - Superior War School), a school that would be the staunchest champion of the National Security Doctrine, which had as one of its main ideologists General Golbery do Couto e Silva - an ex-member of IPÊS, mentor of the SNI

\footnotetext{
${ }^{4}$ Schneider published several articles on the same subject before the publication of this book. See, for instance: Schneider, Nina. "Breaking the 'Silence' of the Military Regime: New Politics of Memory in Brazil?" Bulletin of Latin American Research 30, no. 2 (2011): 198-212; Schneider, Nina. "Impunity in Post-Authoritarian Brazil: the Supreme Court's Recent Verdict on the Amnesty Law". European Review of Latin American and Caribbean Studies 90, no. 1 (2011): 39-54.
} 
(Serviço Nacional de Informações - National Intelligence Service) and its first director, and, in the Geisel term, one of its main ministers. ${ }^{5}$

Those agencies played a very important role in what happened after the coup: the creation of the AERP (Assessoria Especial de Relações Públicas - Special Public Relations Consultancy - 1968/1974) and of the ARP (Assessoria de Relações Públicas - Public Relations Consultancy - 1976/1980). Following a well structured analysis of the several stages of the authoritarian propaganda, Brazilian Propaganda shows that there were few hierarchical relations between the main propaganda organs of the regime and other branches of the government. For instance, one of the most popular propaganda campaigns, "Brasil: ame-o ou deixo-o" ("Brazil: love it or leave it"), was allegedly created in the context of the Bandeirantes Operation, responsible for the organization of the repressive apparatus (mainly the CODI-DOI - Centro de Operações de Defesa Interna Destacamento de Operações de Informações - Center of Internal Defense Operations - Unit of Intelligence Operations).

It is possible to conclude that several films produced by AERP and ARP can be characterized as "subliminal" propaganda. They were not at all naïve, as some would assume. Schneider talks about the cinema and television films in Chapters 2 and 3. Apparently showing mere scenes of everyday life, the films avoid direct discussion of political facts (they were not "blunt" propaganda), but always emphasize the ideas of "order, security and obedience" - mainly those films aiming to educate the public against traffic accidents. Or else, as the book mentions explicitly, they encompass the

\footnotetext{
${ }^{5}$ In his four-volume work, Elio Gaspari tries to stress the importance that Ernesto Geisel and Golbery do Couto e Silva had in creating the authoritarian state and in substituting it for a democratic one. See Gaspari, Elio. As Ilusões Armadas: a Ditadura Envergonhada. Rio de Janeiro: Intrínseca, 2014; Gaspari, Elio. As Ilusões Armadas: a Ditadura Escancarada. Rio de Janeiro: Intrínseca, 2014; Gaspari, Elio. O Sacerdote e o Feiticeiro: a Ditadura Derrotada. Rio de Janeiro: Intrínseca, 2014; Gaspari, Elio. O Sacerdote e o Feiticeiro: a Ditadura Encurralada. Rio de Janeiro: Intrínseca, 2014.
} 
idea of a "typical" Brazilian: one that is a family man and predominantly white; one that doesn't want to be ignorant any more, but wishes to be part of a "cultured society"; one who succeeds in life through hard work in spite of extremely challenging conditions. As the author points out in the introduction, it becomes very difficult to set clear boundaries between what is political and what is not: the 1979 filmete about musicians playing in a village orchestra, and then dressed smartly for a concert, ends with a moralizing voice-over that speaks about an independence achieved with love, work and unity. It is hard not to remember what were the values of love for the "traditional family" that supported the coup, or not to think about what kind of unity is implied in the context of "Brazil: love it or leave it" (nothing could be more Schmittian). ${ }^{6}$

Brazilian Propaganda also aims to show the means by which AERP and ARP used to act. One of the topics that become less recurrent in the Brazilian filmetes is "youth". It is interesting to see how it decreases from 1970-1973 to 1974-1977: appearing at first in $24.7 \%$ of the movies, it steps down to an average of $7.9 \%$. Could we relate this decrease to the repression of the guerrilla groups, most of which were formed by students or young people? Did the goals change because of that? Is it not easier to produce subliminal propaganda when you can hide political discussions, political facts, and chiefly the resistance to the dictatorship? Those questions are related to a broader one. If the distinctions between democracy and autocracy are more blurred than clear as far as investigating propaganda is concerned - as the author herself states at the end of Chapter 1 - one cannot forget that the intention of always assuming the guise of a legal and even legitimate movement stood foremost in the minds of those responsible for institutionalizing the regime. This assumption is not overlooked in Brazilian Propaganda,

\footnotetext{
${ }^{6}$ The authoritarian state was itself responsible for several human rights violations targeted at minority groups, such as homosexuals. See Green, James. Quinalha, Renan (eds.). Ditadura e Homossexualidade: Repressão, Resistência e Busca da Verdade. São Carlos: EdUFSCar, 2014.
} 
of course. IPES and IBAD were founded to make it look like that the coup was popularly legitimized; the preamble of the Institutional Act $\mathrm{n}^{\mathrm{0}}$ 1, of 1964, written by a Brazilian constitutional lawyer, uses the word "revolution" several times; the Institutional Act no 5, of 1968, a "coup inside the coup", speaks in terms of a permanent revolution; even at the Convening of the National Assembly of 1987-1988, that would elaborate and promulgate the Constitution of 1988, the President of the Brazilian Supreme Court (the Supremo Tribunal Federal), Justice Moreira Alves, stated that that occasion was yet another step in the purported "revolution". So, can we really accept that AERP and ARP did not have the clear intention of producing propaganda that could fool the general public away from participation in Brazilian politics?

To Brazilian Propaganda, it looks like this is possible. However, while there was indeed a concealment of the violence apparatus through the propaganda - an argument supported by Carlos Fico, with whom Schneider agrees - it can only be conceived as an ultimate consequence, not a deliberate intent. ${ }^{7}$ Brazilian Propaganda is very persuasive in spelling out that argument. With a huge body of primary sources, like documents and interviews with the main actors responsible for both organs, it is really possible to state that this conclusion flows naturally from the book. The only thing that merits some criticism is that there seems to be an excessive reliance on oral testimonies of persons who were directly involved with the regime and would be anxious to avoid any - even if merely historical - responsibility during these days of transitional justice. Of course some objectivity in investigation is present here, as that principle is stressed throughout the book itself. Still, there seems to be room for a more normative analysis.

\footnotetext{
${ }^{7}$ Fico's argument is in Fico, Carlos. Reinventando o Otimismo: Ditadura, Propaganda e Imaginário Social no Brasil. Rio de Janeiro: Editora Fundação Getúlio Vargas, 1997.
} 
One of the best results of the research presented in Brazilian Propaganda has to do with the relationship between the above-mentioned phenomena and Brazilian media. As the subject of media regulation comes again into the political agenda in Brazil, one cannot forget how some individual media channels, like Globo, benefited directly from their support to the coup and the regime. On the other hand, private companies connected with official advertising were great supporters of the regime during those years when profit was larger. When the market was overtaken by the oil crisis, those companies turned against the same regime responsible for so many human rights violations and became severe critics. Another field that concerned the author is the educational one: recent writings in Brazil have tried to show the degree in which the repression apparatus were institutionalized in universities, which is one extra link between the book and current Brazilian researches in the field. ${ }^{8}$

In short, Brazilian Propaganda is a formidable and genuine contribution to the study of the Brazilian dictatorship of 1964-1985, a subject that has not yet been thoroughly explored even by Brazilian researchers.

\section{References}

Atencio, Rebecca J.. Memory's Turn: Reckoning with Dictatorship in Brazil. Madison: The University of Wisconsin Press, 2014.

Fico, Carlos. Reinventando o Otimismo: Ditadura, Propaganda e Imaginário Social no Brasil. Rio de Janeiro: Editora Fundação Getúlio Vargas, 1997.

Gaspari, Elio. As Ilusões Armadas: a Ditadura Envergonhada. Rio de Janeiro: Intrínseca, 2014.

\footnotetext{
${ }^{8}$ Motta, Rodrigo Patto Sá. As Universidades e o Regime Militar. Rio de Janeiro: Zahar, 2014.
} 
. As Ilusões Armadas: a Ditadura Escancarada. Rio de Janeiro: Intrínseca, 2014.

. O Sacerdote e o Feiticeiro: a Ditadura Derrotada. Rio de Janeiro: Intrínseca, 2014.

. O Sacerdote e o Feiticeiro: a Ditadura Encurralada. Rio de Janeiro: Intrínseca, 2014.

Green, James. Quinalha, Renan (eds.). Ditadura e Homossexualidade: Repressão, Resistência e Busca da Verdade. São Carlos: EdUFSCar, 2014.

Lessa, Francesca. Payne, Leigh A. (eds.). Amnesty in the Age of Human Rights Accountability: Comparative and International Perspectives. Cambridge: Cambridge University Press, 2012.

Meyer, Emilio Peluso Neder. Cattoni de Oliveira, Marcelo Andrade (eds.). Justiça de Transição nos 25 Anos da Constituição de 1988. Belo Horizonte: Initia Via, 2014.

Motta, Rodrigo Patto Sá. As Universidades e o Regime Militar. Rio de Janeiro: Zahar, 2014.

Schneider, Nina. Brazilian Propaganda: Legitimizing an Authoritarian Regime. Gainesville: University Press of Florida, 2014.

. "Breaking the 'Silence' of the Military Regime: New Politics of Memory in Brazil?" Bulletin of Latin American Research 30, no. 2 (2011): 198-212.

. "Impunity in Post-Authoritarian Brazil: the Supreme Court's Recent Verdict on the Amnesty Law". European Review of Latin American and Caribbean Studies 90, no. 1 (2011): 39-54 